Antiseptic skin care of infants with a $3 \%$ hexachlorophane emulsion is shown to be a very effective method of reducing puerperal breast abscess in mothers.

\section{REFERENCES}

Colbeck, J. C. (1949). Canad. med. Ass. f., 61, 557.

(1962). Control of Infections in Hospitals. Hospital Monograph Series, No. 12, p. 54. American Hospital Association, Chicago. Corner, B. D., Crowther, S. T., and Eades, S. M. (1960). Brit. med. F., 1, 1927.

Dietrick, A., and Frangenheim, P. (1926). Neue Dtsch. Chir., 35, 74.

Elek, S. D. (1956). Ann. N.Y. Acad. Sci., 65, 85.

F and Conen, P. E. (1957). Brit. 7. exp. Path., 38, 573.

Fulton, A. A. (1945). Brit. med. F., 1, 693.

Gibberd G. F (1953) Amer. \% Obstec. Gymec., 65, 1038.

Hill, A. M. (1964). Med. F. Aust., 1, 101.

Knight, I. C. S., and Nolan, B. (1959). Brit. med. F., 1, 1224

Knott, F. A., and Blaikley, J. B. (1944). F. Obstet. Gynaec. Brit. Emp., 51, 386.
Möbius, W. (1950). Dtsch. Gesundh.-Wes., 5, 423. Cited by Valentin (1960).

Moon, A. A., and Gilbert, B. (1935). 7. Obstet. Gynaec. Brit. Emp., 42, 268.

Noack, H. (1955). Geburtsh. u. Frauenheilk., 15, 224

Plueckhahn, V. D. (1961). Brit. med. F., 2, 779.

Pluecknd Banks, (1958). Med. F. Aust., 1, 664.

- and Banks, J. (1958). Med. F. Aust., 1, 664.

(1963). Med. F. Aust., 2, 519.

Pyle, L. R. (1948). Amer. F. Obstet. Gynec., 55, 676

Ravenholt, R. T., Wright, P., and Mulhern, M. (1957). New Engl. Y. Med., 257, 789.

Semple, A. B. (1960). Practitioner, 185, 383.

Sherman, A. J. (1956). Obstet. and Gynec., $7,268$.

Simpson, K., Tozer, R. C., and Gillespie, W. A. (1960). Brit. med. Y., 1,315 .

Valentin, H. (1960). Med. Welt (Stuttg.), 2, 121.

Webb, J. F. (1954). Canad. med. Ass. F., 70, 382

Wysham, D. N., Mulhern, M. E., Navarre, G. C., La Veck, G. D., Kennan, A. L., and Giedt, W.' R. (1957). New Engl. J. Med., 257, 304.

\title{
Further Observations on Vaccination in Infancy with Oral Poliomyelitis Vaccine and Diphtheria, Tetanus, Pertussis Vaccine
}

\author{
N. R. BUTLER,* M.D., M.R.C.P., D.C.H. ; P. F. BENSON, † M.B., M.R.C.P., D.C.H. ; \\ J. URQUHART, $\ddagger$ M.B., CH.B., D.P.H. ; A. P. GOFFE, $§$ M.B., DIP.BACT. ; \\ G. J. KNIGHT,§ F.I.S. ; T. M. POLLOCK, $\|$ M.B., СH.B.
}

Brit. med. F., 1964, 2, 418-420

The scheme generally employed at present in Britain for infant immunization requires six visits to the clinic within the first 18 months of life. Three injections of combined diphtheria, tetanus, and pertussis vaccine (triple vaccine) are followed by three doses of oral trivalent poliomyelitis vaccine. By giving the poliomyelitis vaccine concurrently with the triple vaccine the number of visits is reduced to three, and this procedure has been shown to be effective even in very young infants, using a dose of $10^{6}$ of each virus type (Benson et al., 1963). Two further studies have now been made along similar lines, one using smaller doses and the other fewer doses of poliomyelitis vaccine.

\section{Procedure}

The participants were healthy infants attending for routine primary immunization at the infant welfare clinics. Pre-vaccination serum samples were obtained from all infants immediately before their first dose of vaccine. The triple vaccine and the poliomyelitis vaccine (Sabin) were prepared at the Wellcome Research Laboratories. The dose of poliomyelitis vaccine was contained in three drops given directly into the mouth from a dropper bottle, and the triple vaccine was injected subcutaneously. The interval between doses was four weeks. There were two main studies.

Study 1 was designed to assess the efficacy of three doses of $10^{5.5} \mathrm{TCD}_{50}$ of each virus type (group A). While this study was in progress at the University College Hospital, London, the Ministry of Health recommended that the schedule of poliomyelitis vaccination should be three doses of trivalent vaccine,

\footnotetext{
* Immunization Clinic, University College Hospital, London. Present address : Hospital for Sick Children, Great Ormond Street, London. Paediatric Research Unit, Guy's Hospital Medical School, London. $¥$ Medical Officer of Health, Borough of Swindon, Wiltshire. The Wellcome Research Laboratories, Beckenham. If Medical Research Department, the Wellcome Foundation.
}

each dose consisting of $10^{5.7}$ type $1,10^{5}$ type 2 , and $10^{5.5}$ type 3. A second group of children (group B) at University College Hospital and Swindon Public Health Department were accordingly vaccinated by this regime. Study 1 thus consisted of an assessment of each of the above schedules independently, and it was not designed as a comparison of the relative efficacy of the two schedules. In both groups a postvaccination serum sample was taken four weeks after the final dose ; antibody estimations were made in parallel from the preand post-vaccination sample.

In Study 2, made at Salomons' Centre, Guy's Hospital, the infants were placed in three groups according to a table of random numbers. The infants in the first group were given one dose of trivalent poliomyelitis vaccine, in the second group two doses, and in the third group three doses. Post-vaccination serum samples for each group were obtained four weeks after the final dose. Each dose contained $10^{5.7}$ type 1, $10^{5}$ type 2, and $10^{5.5}$ type 3 .

\section{Results in Study 1}

Sixty-three infants were immunized in group A; 29 of these infants were aged 5 to 12 weeks of age; all but two of the remainder were 13 to 28 weeks. There were 58 infants in group B ; eight of these were aged 9 to 12 weeks, the remainder were 13 to 32 weeks (Table I). Group A thus contained a larger proportion of infants who were less than 3 months old than group $B$.

TABLE I.-Age Distribution of Infants in Study 1

\begin{tabular}{r|c|c|c|c|c|c|c|c|c}
\hline Age in weeks: & $5-8$ & $9-12$ & $13-16$ & $17-20$ & $21-24$ & $25-28$ & $29-32$ & $33-36$ & $37-40$ \\
\hline $\begin{array}{r}\text { No. of infants: } \\
\text { Group A (63) } \\
\text { B (58) }\end{array}$ & - & 23 & 19 & 8 & 2 & 3 & - & 1 & 1 \\
\hline
\end{tabular}


As shown in Fig. 1, most of the infants in both groups possessed antibody to one or more virus types before immunization; in the great majority, vaccination was followed by a rise in antibody titre. Seventeen infants in group A had no antibody to type 1 before immunization-15 of these had antibody after immunization. Twelve of the infants in group B had no antibody to type 1 before immunization and all had antibody after immunization. In both groups all infants with no pre- vaccination antibody titre to types 2 and 3 possessed the appropriate antibody after vaccination.

\section{Results in Study 2}

A total of 82 infants took part; 27 were given one dose, 27 two doses, and 28 three doses. Their ages ranged from 5 to

Figure 1, Study 1.-Pre- and Post-vaccination Titres Compared

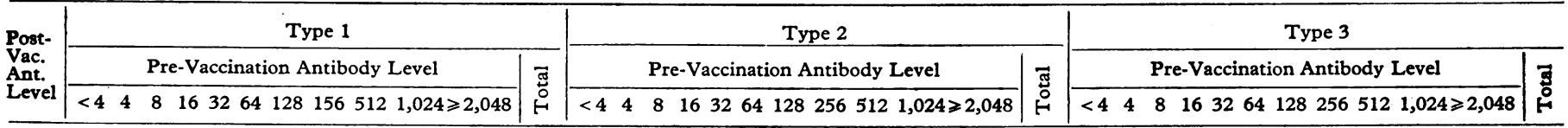

\begin{tabular}{|c|c|c|c|c|c|c|c|c|c|c|c|c|c|c|c|c|c|c|c|c|c|c|c|c|c|c|c|c|c|c|c|c|c|c|c|}
\hline \multicolumn{36}{|c|}{ Group $A$} \\
\hline 2048 & 1 & & $-\overline{-}$ & - & & 1 & 2 & - & & & 12 & 7 & & & & 3 & & & 1 & 4 & & 5 & & & & & & & & & & & & & 26 \\
\hline $\begin{array}{l}1,024 \\
512\end{array}$ & $\overrightarrow{3}$ & $=$ & $\begin{array}{ll}1 & 1 \\
2 & 1\end{array}$ & 1 & & $\overline{1}$ & - & - & - & - & 4 & 2 & - & 1 & $\overline{0}$ & - & 3 & & - & $\overline{1}$ & 2 & & 11 & 1 & 1 & $\overline{0}$ & $\overline{3}$ & $\overline{1}$ & 1 & 2 & 1 & 1 & 2 & 1 & $\begin{array}{l}10 \\
11\end{array}$ \\
\hline $\begin{array}{l}312 \\
256\end{array}$ & 3 & $\overrightarrow{1}$ & 21 & $\frac{2}{2}$ & $\frac{1}{3}$ & $\begin{array}{l}1 \\
1\end{array}$ & $\overline{1}$ & $\overline{1}$ & $\overline{-}$ & $\bar{z}$ & $\begin{array}{l}10 \\
12\end{array}$ & $\frac{2}{-}$ & $\bar{z}$ & $\bar{z}$ & 2 & $\bar{z}$ & 2 & & $\bar{i}$ & 1 & $\overline{-}$ & & $\begin{array}{l}8 \\
2\end{array}$ & $\begin{array}{l}1 \\
4\end{array}$ & & 2 & $\begin{array}{l}3 \\
1\end{array}$ & $\begin{array}{l}1 \\
1\end{array}$ & 2 & $\frac{1}{2}$ & $\overline{-}$ & [ & & $\overline{-}$ & \\
\hline 128 & 4 & $\overline{-}$ & & 2 & - & 2 & - & 1 & - & - & 10 & & 1 & - & - & 1 & & 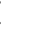 & 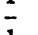 & 1 & 1 & - & 5 & - & & - & - & - & 2 & 1 & 1 & - & & - & \\
\hline $\begin{array}{l}64 \\
32\end{array}$ & 1 & $\overline{-}$ & & $\begin{array}{l}- \\
-\end{array}$ & $\overrightarrow{1}$ & 2 & - & $\bar{z}$ & $\overline{-}$ & $\bar{z}$ & $\begin{array}{l}6 \\
3\end{array}$ & $\overline{-}$ & $\overline{-}$ & $\overline{-}$ & $=$ & $\overline{-}$ & E & 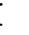 & $\underline{1}$ & $\begin{array}{l}z^{\prime} \\
\end{array}$ & $\overline{-}$ & & 1 & $\overline{-}$ & & 1 & $\overline{-}$ & $\overline{-}$ & $\underline{1}$ & $\overline{-}$ & $\overline{-}$ & $\overline{-}$ & & $\overline{-}$ & \\
\hline $\begin{array}{r}16 \\
8\end{array}$ & 1 & $\bar{z}$ & & $\bar{z}$ & $\overline{-}$ & $\overline{1}$ & $\overline{-}$ & $\overline{-}$ & $\overline{-}$ & $\bar{z}$ & 2 & $\overline{-}$ & $z$ & $\bar{z}$ & z & $\bar{z}$ & $z$ & 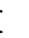 & $\overline{-}$ & $\overline{-}$ & $\overline{-}$ & & $\overline{-}$ & $\overline{-}$ & & $\begin{array}{c}- \\
\end{array}$ & $=$ & $=$ & $\overline{-}$ & $\overline{-}$ & $\overline{-}$ & $\overline{-}$ & & $\overline{-}$ & \\
\hline $\begin{array}{r}4 \\
<4\end{array}$ & $\overline{2}$ & $\bar{z}$ & & $\overline{1}$ & $\overline{-}$ & $\overline{-}$ & $\overline{-}$ & $\bar{z}$ & - & $\bar{z}$ & $\frac{1}{3}$ & & $\bar{z}$ & $\overline{-}$ & $\overline{-}$ & & - & & $\overline{-}$ & $\overline{-}$ & $\overline{-}$ & & $\overline{-}$ & $\overline{-}$ & & $\overline{-}$ & $\overline{-}$ & $\bar{z}$ & z & $\overline{-}$ & $=$ & $\overline{-}$ & & $\bar{z}$ & \\
\hline Total & 17 & 1 & 54 & 8 & 8 & 8 & 4 & 2 & 3 & 3 & 63 & 11 & 3 & 2 & 3 & 4 & 9 & 7 & 3 & 6 & 8 & 7 & 63 & 14 & 4 & 6 & 4 & 4 & 9 & 6 & 5 & 1 & 7 & 3 & 63 \\
\hline
\end{tabular}

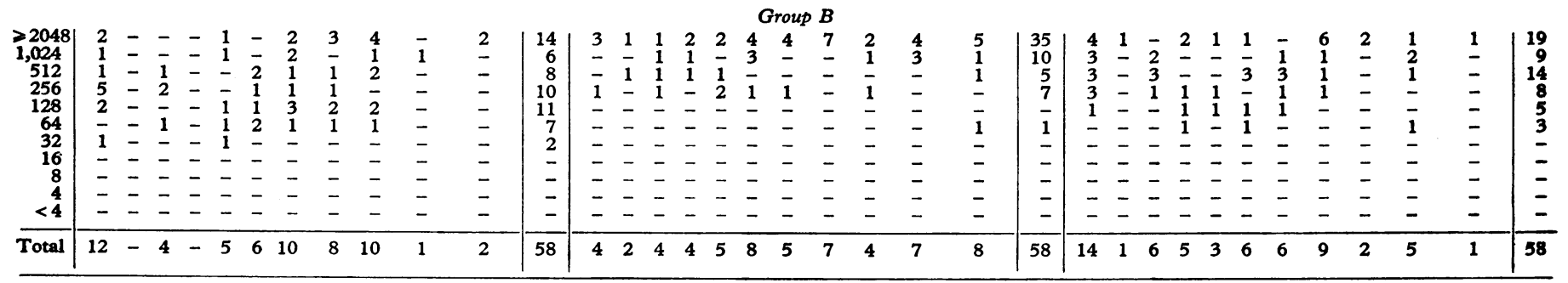

Figure 2, Study 2.-Pre-and Post-vaccination Titres Compared.

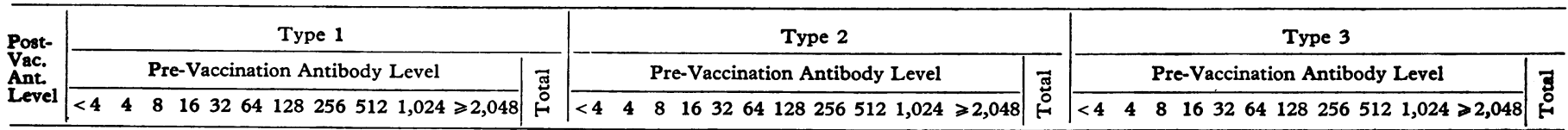

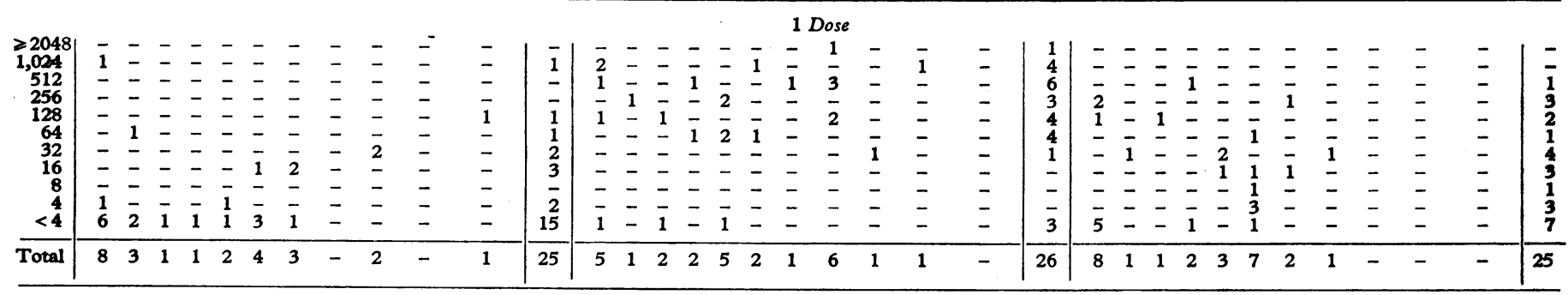

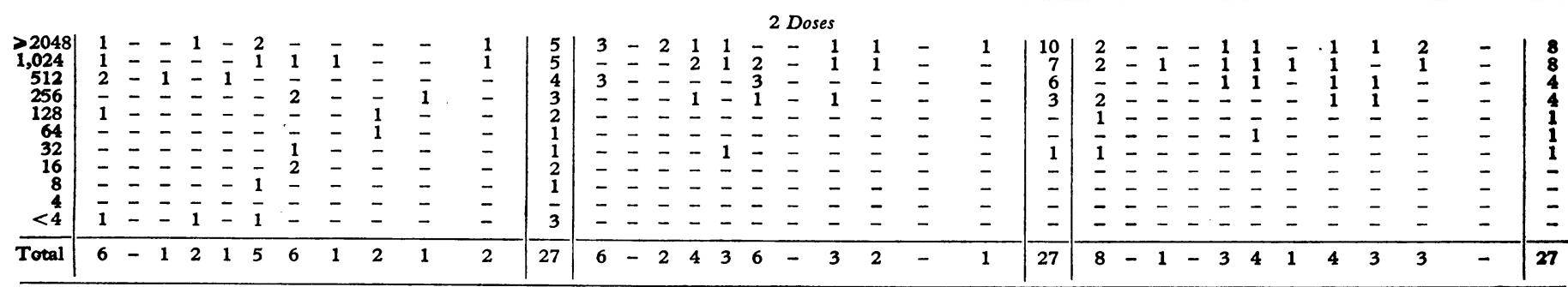

\begin{tabular}{|c|c|c|c|c|c|c|c|c|c|c|c|c|c|c|c|c|c|c|c|c|c|c|c|c|c|c|c|c|c|c|c|c|c|c|c|}
\hline & \multicolumn{35}{|c|}{3 Doses } \\
\hline $\begin{array}{r}128 \\
64\end{array}$ & & & & $=$ & $\overline{-}$ & - & - & - & $=$ & $=$ & 3 & 1 & - & E & & $\underline{z}$ & & i & $\overline{1}$ & & $\overline{-}$ & $\bar{z}$ & & 4 & - & 1 & 1 & - & 1 & - & $=$ & $=$ & - & - & 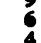 \\
\hline $\begin{array}{r}16 \\
8\end{array}$ & & - & & $\bar{z}$ & $\begin{array}{l}- \\
-\end{array}$ & $\begin{array}{l}z^{\prime} \\
\text { - }\end{array}$ & $\overline{-}$ & $\overline{-}$ & - & $z$ & 1 & $\overline{-}$ & $\overline{-}$ & $z$ & 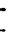 & z & 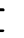 & & $\overline{-}$ & $\bar{z}$ & $\Xi$ & & $\overline{-}$ & $\overline{-}$ & $z$ & $\overline{-}$ & $\overline{1}$ & $\overline{-}$ & $z$ & $\bar{z}$ & $\overline{-}$ & $=$ & $=$ & $\overline{-}$ & \\
\hline $\begin{array}{r}4 \\
<4\end{array}$ & 1 & $\bar{z}$ & $\bar{z}$ & $\overline{-}$ & $\overline{-}$ & $\overline{-}$ & $\bar{z}$ & - & $=$ & $\overline{-}$ & 1 & $\overline{-}$ & $\overline{-}$ & z & & $=$ & & E & $=$ & $z$ & - & $\bar{z}$ & $=$ & $\bar{z}$ & 1 & - & $=$ & $=$ & z & - & z & - & - & - & \\
\hline Total & 9 & -3 & 5 & 4 & 1 & 3 & 1 & 1 & - & 1 & 28 & 8 & - & - & & 5 & ! & 3 & 3 & 2 & 1 & - & 28 & 11 & 1 & 3 & 4 & 2 & 4 & 1 & 1 & - & - & - & 7 \\
\hline
\end{tabular}


24 weeks, the majority being 9 to 16 weeks at the time of the first immunization. The ages of the infants in the three groups were closely similar (Table II).

For the infants given a single dose of vaccine, serum samples were not available for two type 1 antibody titres, one type 2 , and two type 3. For the infants given three doses, serum samples were not available for one type 3 titre.

TABLE II.-Age Distribution of Infants in Study 2

\begin{tabular}{c|c|c|c|c}
\hline \multirow{3}{*}{ Age (Weeks) } & \multicolumn{4}{|c}{ No. of Infants } \\
\cline { 2 - 5 } & 1 Dose & 2 Doses & 3 Doses & All Groups \\
\hline $5-8$ & 3 & 2 & 2 & 7 \\
$9-12$ & 15 & 17 & 18 & 50 \\
$13-16$ & 5 & 3 & 7 & 15 \\
$17-20$ & 2 & 3 & 1 & 6 \\
$21-24$ & 2 & 2 & - & 4 \\
\hline Total & 27 & 27 & 28 & 82 \\
\hline
\end{tabular}

The antibody response to each dose has been assessed by the proportion of infants without pre-vaccination antibody who developed antibody after vaccination; by the proportion of those already possessing antibody before vaccination whose titre either rose or showed no decline after vaccination; (since the maternally derived pre-vaccination antibody would be expected to decline during the period between the first and second samples, an equal or greater titre in the second sample indicates a response) ; and by the proportion of the infants with relatively low pre-vaccination antibody titres (4-64) who showed a fourfold or greater rise after vaccination.

Type 1.-Among initially antibody-free infants two out of eight responded after one dose, five out of 6 after two doses, and eight out of nine after three doses. The proportion of infants with pre-vaccination antibody showing no evidence of antibody decline after one dose was 1 out of 17, after two doses 11 out of 21 , and after three doses 17 out of 19 . Fourfold or greater rises of titre from an initial level in the range 4-64 occurred in six out of nine after two doses and in 10 out of 13 after three doses.

Type 2.-Among initially antibody-free infants four out of five responded after one dose, all six infants after two doses, and all eight infants after three doses. Sixteen out of 21 infants with pre-vaccination antibody showed no decline in titre after one dose, all 21 infants after two doses, and 18 out of 20 after three doses. Fourfold or greater rises in titre from an initial level in the range 4-64 occurred in 7 out of 12 infants after one dose, in 14 out of 15 after two doses, and in 9 out of 11 after three doses.

Type 3.-Among initially antibody-free infants three of eight responded after one dose, all eight infants after two doses, and all 11 after three doses. Seven out of 17 infants with. prevaccination antibody showed no decline in titre after one dose ; 14 out of 15 after two doses; and 15 out of 16 with three doses. Fourfold or greater rises in titre from an initial level in the range 4-64 occurred in 3 out of 14 infants after one dose, in seven out of eight after two doses, and in 12 out of 14 after three doses.

\section{Discussion}

The results of Study 1 confirm those reported previously (Benson et al., 1963). They indicate that infants may be effectively immunized by giving the oral poliomyelitis vaccine concurrently with a triple vaccine, and thus immunization against these four diseases may be accomplished by three visits to the clinic instead of six. The findings of the present study, and the report previously published (Benson et al., 1963) relate to about 200 infants given the combined regime. In the original study large doses of the trivalent vaccine were employed -namely, $10^{6}$ for each virus type. The current studies indicate that infants may be immunized with smaller doses and that such large doses of all virus types are unnecessary. The trivalent vaccine recommended by the Ministry of Health at the present time contains more type 1 than types 2 and 3 . However, since immunization is effective when the dose of each virus type is $10^{5.5}$, it would appear that the precise dosage is not critical.

In the second study a comparison was made of the antibody response to trivalent vaccine after one, two, and three doses ( $10^{5.7}$ type $1,10^{5}$ type 2 , and $10^{5.5}$ type 3 ). One dose was found to be insufficient for effective immunization against type 1 and type 3 although there was an adequate response to type 2. This is in keeping with the findings of the Medical Research Council (1962), who also reported that one dose of trivalent vaccine was ineffective in infants. Either two or three doses of vaccine produced an effective antibody response to all three virus types in the absence of pre-vaccination antibody. When pre-vaccination antibody was present there was a satisfactory response to either two or three doses of types 2 and 3 , but there was some indication that three doses may be better than two in the presence of type 1 antibody.

A two-dose regime in which a single dose of type 1 is followed by types 2 and 3 combined has also been shown to be as effective as three single doses of each virus type in older children and adults (Schar et al., 1963). Thus in the general population three-dose regimes do appear not to be essential for effective poliomyelitis immunization.

Taking all these considerations into account, it seems that two doses of poliomyelitis vaccine by mouth will provide adequate protection for older children and adults in the United Kingdom. For infants three doses of poliomyelitis vaccine may be required, and they can be given concurrrently with a triple vaccine.

\section{Summary}

One hundred and twenty-one infants, of whom most were between the ages of 6 and 28 weeks, were given oral poliomyelitis vaccine concurrently with injections of triple vaccine (diphtheria, tetanus, and pertussis); the dose of poliomyelitis vaccine was either $10^{5.5} \mathrm{TCD}_{50}$ of each virus type or $10^{5.7}$ type $1,10^{5}$ type 2 , and $10^{5.5}$ type 3 .

Eighty-two infants concurrently injected with triple vaccine were given one or two or three doses of oral trivalent poliomyelitis vaccine. The antibody response to one dose was inadequate, but there was a good antibody response to both two and three doses. Three doses, however, produced the best response when maternal antibody to type I was present.

Immunization of infants with poliomyelitis vaccine and triple vaccine given concurrently is preferable to the current practice of giving each vaccine separately, since concurrent administration reduces the number of clinic attendances from six to three.

We thank the mothers of the infants who participated. We also thank Mr. Michelli for his help with the diagrams; Dr. R. E. Bonham-Carter, Sister Curtis, and the staff of the Child Welfare Department, University College Hospital ; and Dr. R. C. MacKeith, Miss M. Theisen, and the staff of Salomons' Centre, Guy's Hospital.

\section{REFERENCES}

Benson, P. F., Butler, N. R., Costello, J. M., Urquhart, J., Barr, M., Goffe, A." P., Knight, G.'J., and Pollock, T. M. (1963).' Brit. med. f., 1, 641 .

Medical Research Council (1962). Ibid., 2, 142.

Schar, M., Lindermann, J., Goffe, A., P., Knight, G. J., and Pollock, T. M. (1963). Med. Offr, 110, 251. 